DARIA HeJWOSZ-GROMKOWSKA

ORCID 0000-0003-2144-9600

Uniwersytet im. Adama Mickiewicza

$w$ Poznaniu

\title{
JAMES BOND \\ A DYLEMATY TOŻSAMOŚCIOWE BRYTYJCZYKÓW - KULTURA POPULARNA A KSZTAŁTOWANIE TOŻSAMOŚCI NARODOWEJ
}

\begin{abstract}
AвStRAct. Hejwosz-Gromkowska Daria, James Bond a dylematy tożsamościowe Brytyjczyków - kultura popularna a ksztattowanie tożsamości narodowej [James Bond and the Identity Dilemmas of the British - Popular Culture and Shaping National Identity]. Studia Edukacyjne nr 58, 2020, Poznań 2020, pp. 85-105. Adam Mickiewicz University Press. ISSN 1233-6688. DOI: 10.14746/se.2020.58.5
\end{abstract}

The author assumes that popular culture plays a powerful role in the process of socialization of young generation. The author tries to present that the conventional national symbols are being replaced by pop symbols and thus become the sources of national identity. The concepts of banal nationalism put forward by Michael Billig or Tim Enderson's idea of everyday life's practices in the development of national identity are being used. In the text, the phenomenon of James Bond is used to analyze the contemporary debates on British identity (Britishness). The author assumes that James Bond is a great example of Englishness that serves as a complex manifestation of a British hero which may, in turn, play a crucial role in political, civic, and patriotic education.

Key words: popular culture, national identity, citizenship education

(...) musi utrzymać równowage między fantazja a rzeczywistością ${ }^{1}$

Kingsley Amis o tożsamości Agenta 007

Zbyszko Melosik w licznych publikacjach poświęconych rozważaniom nad kulturą popularną stawiał tezę, że stanowi ona jedną z najsilniejszych agend socjalizujących młodzież ${ }^{2}$. Z tak obranej perspektywy zakładam, że kultura popularna kształtuje tożsamość współczesnego pokolenia adolescentów, stanowiąc

${ }^{1}$ K. Amis, The James Bond Dossier, New York 1965, s. 6.

2 Zob. m.in. Z. Melosik, Tożsamość, ciało i władza. Teksty kulturowe jako (Kon)teksty pedagogiczne, Toruń - Poznań 1996; Kryzys męskości w kulturze wspótczesnej, wyd. II poprawione, Kraków 2006; Teoria i praktyka edukacji wielokulturowej, Kraków 2007; Tożsamość ciato i władza w kulturze instant, Kraków 2010; Kultura popularna i tożsamość młodzieży. W niewoli władzy i wolności, Kraków 2013. 
zatem istotny obszar badań dotyczący problematyki pedagogiki młodzieży. Ponadto, współczesne podejście do pedagogiki nie ogranicza się jedynie do jej wymiaru szkolnego, ale także do codziennych praktyk kulturowych ${ }^{3}$. Odejście od redukcjonistycznej roli pedagogiki pozwala na eksploracje praktyk edukacyjnych poza murami szkoły, w różnych - często naturalnych dla młodego człowieka - środowiskach czy instytucjach. Bez wątpienia, takim obszarem są media, które w wiodący sposób przekazują praktyki i wzory popkulturowe. Współcześnie wszechobecność i wszechmoc mass mediów powoduje, że nie tylko „reprezentują [one] rzeczywistość, ile ją wytwarzają”, co zostało określone przez Jeana Baudillarda jako hiperrzeczywistość . Podobne stanowisko prezentuje Paul Hodkinson, twierdząc, że media nie są zwierciadłem społeczeństwa, lecz konstruują rzeczywistość, która z kolei wpływa na społeczne relacje oraz wyznawane wartości ${ }^{5}$. Z tej perspektywy można zaakceptować tezę, iż media kreują również potrzeby odbiorców, także te dotyczące stylu życia, organizowania własnej ścieżki kariery oraz orientacji rodzinnych ${ }^{6}$. Można zatem zauważyć, iż współcześnie kultura popularna będzie również formowała określone wzory zachowań i postaw obywatelskich, a także - co będzie przedmiotem dalszych rozważań - stanie się źródłem dla (re)(de)konstruowania tożsamości indywidualnej oraz kolektywnej.

W literaturze przedmiotu można znaleźć poparcie dla tezy, że kultura popularna kształtuje również tożsamość narodową oraz poczucie wspólnotowości. Tim Edensor zakładał, że tożsamość narodowa konstruowana jest na podstawie praktyk życia codziennego, do których zalicza udział w popkulturze $^{7} . \mathrm{Z}$ tak obranej perspektywy, podejmuję $\mathrm{w}$ niniejszym artykule próbę (re)konstrukcji debaty dotyczącej kształtowania tożsamości brytyjskiej (Britishness) i towarzyszących jej dylematów w kontekście zjawisk popkultury na przykładzie postaci Jamesa Bonda.

\section{Współczesne podejścia wobec tożsamości brytyjskiej (Britishness)}

Kwestia tożsamości narodowej w Wielkiej Brytanii wydaje się problematyczna, nade wszystko z powodów uwarunkowań historycznych związanych

${ }^{3}$ T. Szkudlarek, Television as adult pedagogy: Learning Consumersim, Dreaming, Democracy, [w:] Adult Education and Democratic Citizenship, red. A. Bron, J. Field, E. Kurantowicz, Kraków 1998, s. 71-72.

${ }^{4}$ Tamże, s. 72.

${ }^{5}$ P. Hodkinson, Media, culture and society. An introduction, London 2011, s. 266.

${ }^{6}$ Tamże, s. 269.

${ }^{7}$ Zob. T. Edensor, Tożsamość narodowa, kultura popularna i życie codzienne, przekł. A. Sadza, Kraków 2004. 
z kolonizacją oraz społecznymi i prawnymi konsekwencjami. Współcześnie budzi ona wiele kontrowersji, bowiem w ostatnich latach kategoria brytyjskości staje się coraz bardziej pojemna pojęciowo w dyskursie publicznym ${ }^{8}$. Poczucie brytyjskości oznacza zdolność do identyfikacji z monarchią, demokracją parlamentarną, Imperium oraz z chwalebnymi wojskowymi zwycięstwami. Linia podziału między tym, co brytyjskie (nasze, wspólne) a tym, co obce (inne) pozwalała na zrozumienie i zinternalizowanie wspólnych wartości dla narodu brytyjskiego. Miało to szczególne znaczenie w okresie kolonizacji, gdyż kształtowało poczucie wyższości wśród Brytyjczyków nad podbitymi ludami, które postrzegane były jako prymitywne. Sami Brytyjczycy przedstawiali siebie jako tych, którzy torowali drogę do cywilizacji9

Wokół kategorii Britishness toczą się liczne dyskusje w społeczeństwie brytyjskim. Wraz z dojściem do władzy Partii Pracy pod koniec lat dziewięćdziesiątych ubiegłego wieku ponownie zaczęto przywiązywać wagę do tej kategorii. Wzrost zainteresowania brytyjskością spowodowało w istocie wiele czynników, a wśród nich: niebezpieczeństwo bałkanizacji Wielkiej Brytanii, nadmierna ingerencja - w opinii Brytyjczyków - Unii Europejskiej, niepewna pozycja $\mathrm{w}$ relacjach ze Stanami Zjednoczonymi, a także procesy globalizacyjne i wyłonienie się idei globalnego obywatelstwa. Podjęto wówczas próbę (re)definiowania pojęcia angielskości oraz brytyjskości i skonfrontowano je z procesami imigracyjnymi. Można też przyjąć za niektórymi badaczami przedmiotu, że do poszukiwania i odkrywania brytyjskości, a także do pojawienia się dyskursu obywatelstwa w Wielkiej Brytanii przyczynił się wzrost liczby imigrantów ${ }^{10}$.

Za czasów liderowania Partii Pracy (1997-2010) niektórzy politycy utrzymywali, że należy promować "powszechne narodowe obywatelstwo" jako narzędzie budowania jedności społecznej. Innymi słowy, źródłem edukacji obywatelskiej i budowania spójności narodowej (social cohesion) powinna być szeroko pojęta brytyjskość. Na przykład, w 2006 roku Gordon Brown, ówczesny kanclerz skarbu, stwierdził, że należy mówić o idei brytyjskości, bowiem to Brytyjczycy ofiarowali światu umiłowanie dla wolności i sprawiedliwości ${ }^{11}$. Krytycy takiego podejścia zauważyli jednak, że nie taką drogą osiągnie się pożądaną równość społeczną, bowiem wykluczeni zostaną ci, którzy nie dzielą wartości skoncentrowanych wokół brytyjskości. Ponadto, oznaczałoby

${ }^{8}$ Zob. D. Hejwosz-Gromkowska, Edukacja obywatelska we wspótczesnej Anglii. Studium socjopedagogiczne, Poznań 2019.

9 J. Beck, A briefhistory of citizenship education in England and Wales, [w:] Debates in citizenship education, red. J. Arthur, H. Cremin, London - New York 2012, s. 4.

${ }^{10} \mathrm{~K}$. Kumar, English and French national identity: comparisons and contrasts, Nations and Nationalism, 2006, 12(3), s. 424.

${ }^{11} \mathrm{~J}$. Beck, A brief history of citizenship education, s. 10. 
to powrót do asymilacjonizmu i odrzucenia idei wielokulturowości ${ }^{12}$, co z kolei ma szczególne znaczenie w sytuacji, w której Wielką Brytanię określa się jako „hiper-różnorodną”, a dane demograficzne wskazują na wzrost liczby populacji migrantów i ich pokoleń w następnych latach ${ }^{13}$. Z kolei, G. Brown jako premier w 2008 roku wzywał do tworzenia „brytyjskich miejsc pracy dla Brytyjczyków”. Była to odpowiedź na falę imigracji z Europy Wschodniej oraz na popularne wówczas medialne doniesienia, jakoby robotnicy ze Wschodu zabierali pracę Brytyjczykom, przy jednoczesnym korzystaniu z wszelkich przywilejów socjalnych. Innymi słowy, zostali oni naznaczeni jako ci, którzy nie są „z nami", nie należą do naszego narodu, a prawnie zabierają nam to, co nasze ${ }^{14}$. W ten sposób budowanie jedności społecznej, promowane przez laburzystów, odbywało się poprzez wykluczanie „innych" i „obcych”. Próbowali oni również powołać do życia brytyjski patriotyzm, który w opinii Audrey Osler jawi się raczej jako coś niebrytyjskiego (np. próby wprowadzenia święta flagi czy święta narodowego) ${ }^{15}$, bowiem w tradycji narodu brytyjskiego nie rozwinął się patriotyzm tak, jak miało to miejsce w przypadku innych narodów europejskich.

Przedstawiciele Partii Konserwatywnej, która doszła do władzy w 2010 roku, również w swoich postulatach w punkcie centralnym stawiali ową brytyjskość jako rdzeń tożsamości i podstawę budowania jedności narodowej. Konserwatyści także widzą potrzebę inkluzji brytyjskości przez grupy mniejszościowe, włączając je w konsekwencji w proces budowania jedności społecznej/narodowej (social cohesion), co również zrywało z ideologią multikulturalizmu. Polityce brytyjskości - zapoczątkowanej przez laburzystów - zarzuca się powielanie dawniejszych liberalnych poglądów Wigów na kwestie narodowe, których zadaniem było uspokojenie ówczesnej klasy średniej i wygaszanie pojawiającego się angielskiego nacjonalizmu ${ }^{16}$.

Należy przyznać, iż koncepcja brytyjskości nadal pozostaje kategorią trudną do zdefiniowania, bowiem jej znaczenie jest odmiennie rozumiane przez różne grupy społeczne ${ }^{17}$. Co więcej, nie jest ona kategorią stałą, zresztą nigdy nią nie była, przeciwnie: płynną, fluktuacyjną i akomodacyjną ${ }^{18}$.

\footnotetext{
${ }^{12}$ Tamże.

${ }^{13}$ A. Malik, Citizenship education, race and community cohesion, [w:] Debates in citizenship education, red. J. Arthur, H. Cremin, London - New York 2012, s. 67.

${ }^{14} \mathrm{R}$. Sales, What is 'Britishness', and is it important?, [w:] Citizenship acquisition and national belonging, red. G. Calder, D. Cole, J. Seglow, London 2010, s. 123.

${ }_{15}$ A. Osler, Citizenship education, democracy and racial justice 10 years on, Race Equality Teaching, 2009, 27(3), s. 23.

${ }^{16}$ R. Andrews, A. Mycock, Dilemmas of Devolution: The 'Politics of Britishness' and Citizenship Education, British Politics, 2008, 3, s. 150.

17 R. Sales, What is 'Britishness', and is it important?, s. 124.

${ }_{18}$ Por. P. Ward, The end of Britishness? A historical perspective, British Politics Review, 2009, 4(3), s. 3.
} 
W sferze praktyki społecznej brytyjskość ma połączyć w całość tożsamości poszczególnych narodów brytyjskich. Jednak w praktyce mieszkańcy Wielkiej Brytanii bardziej identyfikują się ze swoim krajem, a brytyjskość najczęściej traktują w kategorii statusu i określonych praw obywatelskich. Częściej spotkamy tożsamość angielską, szkocką, walijską, irlandzką niż brytyjską ${ }^{19}$. Biorąc pod uwagę pierwiastek emocjonalny, K. Kumar zauważa, że stosunek do własnej narodowości Anglików, Szkotów, czy Walijczyków jest ciepły, natomiast do brytyjskości - bardziej zimny i zdystansowany ${ }^{20}$. Brytyjskość dla pokolenia urodzonego po szóstej dekadzie XX wieku, w odróżnieniu od tego urodzonego przed zakończeniem drugiej wojny światowej, postrzegana jest w kategoriach obywatelskich (40\%), a zatem mniejsze znaczenie dla jego przedstawicieli mają kwestie miejsca urodzenia, pochodzenia przodków, czy przestrzegania tradycji i zwyczajów, co z kolei jest bliższe starszemu pokoleniu. Co więcej, ci postrzegający brytyjskość głównie przez pryzmat etniczności są bardziej przeciwni imigracji. Z kolei ci, którzy w brytyjskości akcentują przede wszystkim jego wymiar obywatelski, są bardziej proeuropejscy w odróżnieniu od tych, którzy utożsamiają tożsamość brytyjską z etnicznością ${ }^{21}$. Współczesna debata na temat wspólnej tożsamości i podzielanych wartości dotyczy w znacznej mierze budowania jedności społecznej i narodowej podzielonego etnicznie i geograficznie państwa.

\section{Kultura popularna a tożsamość narodowa}

W tradycyjnym ujęciu socjologicznym uznaje się, że jednym z elementów budowania więzi narodowej jest wspólna kultura, a zatem język, zwyczaje, tradycje, religia, obrzędy, ale także literatura, muzyka i sztuka. Trzeba podkreślić, że przez wiele dekad kultura popularna nie stanowiła części dyskursu kultury narodowej, bowiem traktowana była jako gorsza, a nawet niegodna zestawiania jej ze „świętymi” symbolami narodowymi. Sama też rzadko stanowi część praktyki pedagogicznej i edukacyjnej w zachodnich społeczeństwach, w przeciwieństwie już do kultury ludowej, według Tima Edensora, celebrowanej i epatującej przypisanymi jej wartościami narodowymi oraz zbiorem „prawdziwych" praktyk kulturowych. Jawi się ona jako autentyczna, bowiem pokazuje - z perspektywy historycznej - "naturę" narodu, jego życie i obyczaje, które odbywały się w konkretnym miejscu i czasie. O ile wytwory tak

19 Z. Layton-Henry, Citizenship and nationality in Britain, [w:] Challenging racism in Britain and Germany, red. Z. Layton-Henry, C. Wilpert, London 2003, s. 61.

${ }^{20}$ K. Kumar, The Making of English National Identity, Cambridge 2003, s. 6.

${ }^{21}$ A. Park, C. Bryson, J. Curtice, British Social Attitudes 31, NatCen 2014, adres internetowy: http://www.bsa.natcen.ac.uk/media/38893/bsa31_full_report.pdf [dostęp: 20.04.2018], s. 64, 72. 
zwanej kultury wysokiej, jak i kultury ludowej stanowią - w modernistycznej narracji narodowotwórczej - podstawę dla budowania tożsamości narodowej oraz biorą udział w procesach narodowotwórczych, tak produkty kultury popularnej są kojarzone z rynkiem i przemysłem, a nie tożsamością narodową ${ }^{22}$. Ponadto, nie można zapominać - o czym wielokrotnie pisał Zbyszko Melosik - że kultura popularna jest zamerykanizowana, bo niejako „mówi” po angielsku i w głównej mierze odwołuje się do amerykańskich symboli. Badacze przedmiotu zwracają uwagę na pojawienie się w latach dziewięćdziesiątych dwudziestego wieku takich fenomenów, jak „makdonaldyzacja” czy „coca -kolonizacja"23, wskazując, że mamy do czynienia z nowym imperializmem o charakterze toksycznej „westernizacji”24. Amerykańska kultura masowa zastąpiła - by nie rzec, że wyparła w procesie homogenizacji kulturowej będącej efektem globalizacji - lokalną, ludową kulturę, a w wielu miejscach w efekcie kreolizacji wytworzyła nowe hybrydyczne fenomeny kulturowe oraz hybrydyczne tożsamości. Jednakże, według teoretyków kulturowej globalizacji, kultura globalna nie ma jedynie charakteru amerykańskiego, lecz jest wynikiem mieszania się lokalnych praktyk kulturowych, tworząc $\mathrm{w}$ ten sposób hybrydyczną kulturę globalną ${ }^{25}$. Odrzuca się zatem podejście krytykujące globalizację kultury rozumianej jedynie przez pryzmat amerykanizacji oraz komercjalizacji. Teoretycy, tacy jak Jan Nederveen Pieterse czy Ankie Hoogvelt ${ }^{26}$, utrzymują, że owa hybrydyczność kultury stanowi kolejny etap rozwoju cywilizacji i znajduje się w centralnym punkcie postkolonialnego dyskursu. Według tego podejścia, w odróżnieniu od kolonializmu, globalizacja kultury nie jest wcale opresyjną formą, lecz oferującą jednostce możliwość negocjacji i odnajdywania się w pewnej różnorodności. Zważmy, że kultura globalna kwestionuje modernistyczne narracje kulturowe, stałe i monolityczne tożsamości, stąd hybrydyczność, o której mowa, dopuszcza swoiste zerwanie z rygorystycznym podejściem wobec tożsamości narodowej, bowiem staje się ona płynna, otwarta na dialog i negocjacje. Hybrydyczność kulturowa może być postrzegana przez niektórych jako czynnik wzmacniający tezę o końcu państwa narodowego oraz o osłabieniu nacjonalizmu. Jednak państwo narodowe, mimo istnienia przesłanek o jego osłabieniu, nadal pozostaje głównym, aczkolwiek ambiwalentnym źródłem dla kształtowania zarówno kultury na-

${ }^{22}$ T. Edensor, National Identity, Popular Culture and Everyday Life, Oxford 2002, s. 14.

${ }^{23}$ Zob. J.P. Nederveen Pieterse, Globalization and Culture: global mélange, Lanham 2009; Z. Melosik, Teoria i praktyka edukacji wielokulturowej; tenże, Tożsamość ciało $i$ władza w kulturze instant.

${ }^{24}$ Zob. M. Featherstone, Global culture: An introduction, Theory, Culture \& Society, 1990, 7(2-3), s. 1-14.

${ }^{25}$ Zob. J.P. Nederveen Pieterse, Globalization and Culture.

${ }^{26}$ Zob. A. Hoogvelt, Globalisation and the Postcolonial World, London 1997. 
rodowej, jak i tożsamości ${ }^{27}$. Nie jest bowiem tak, że to, co lokalne, narodowe przestało mieć znaczenie w tworzeniu kultury oraz nadawaniu znaczeń wytworom kulturowym. Wydaje się jednak, że topos kulturowy świata zachodniego uległ rozmyciu, a globalizacja wymusza potrzebę mobilności, zatem przynależność do miejsca nie jest trwała, a samo to miejsce przestaje być jedynym źródłem kulturowym dla budowania tożsamości. W kulturze obserwuje się również zjawisko „nowego tradycjonalizmu”, polegające na szukaniu korzeni tożsamości w etniczności, rasie, mniejszościach językowych, czy lokalnych społecznościach. W ten oto sposób eksponuje się, a nawet celebruje, ową różnorodność globalnej kultury, w której granice zostają zamazane, są płynne, a co J.P. Nederveen Pieterse określił jako międzylokalne, zewnętrzne poszukiwanie poczucia przynależności do miejsca ${ }^{28}$.

Współcześnie państwo narodowe konkuruje z innymi podmiotami w dyskursywnej walce o nadawanie znaczenia wytworom kultury. Tak zwana kultura wysoka - ceniona przez elity - traci swój dawny status jako poważnej, jedynej i właściwej, chociaż Tim Edensor zwraca uwagę, że „narodowe elity, rządy oraz wysocy urzędnicy są wciąż przekonani, że «wysoka» kultura jest tym, z czym należy kojarzyć naród, jest tym, co wyróżnia go spośród innych narodów" ${ }^{29}$. Jej wyznacznikami mogą być narodowe galerie, opery, teatry, towarzystwa naukowe i inne instytucje tak zwanej kultury wysokiej. Odwołania do niej widać szczególnie w przypadku pedagogiki szkoły, gdyż codzienne praktyki kulturowe oraz wytwory kultury popularnej są w niej marginalizowane, czego dowodem mogą być treści zawarte w szkolnych podręcznikach czy programach kształcenia.

Przez dekady uważano, że codzienne praktyki kulturowe, takie jak słuchanie muzyki, oglądanie filmów, a nawet spożywanie posiłków, mogą wskazywać, do jakiej grupy społecznej dana jednostka należy. Rozważania na ten temat prowadził między innymi Pierre Bourdieu. Niektórzy zaangażowani w temat obserwatorzy nadal - okazuje się - widzą adekwatność podziałów i kategoryzacji, jakie ów badacz zaproponował. Niemniej jednak - powtórzę - globalizacja oraz zamazywanie się granic między klasami społecznymi, wyrażające się między innymi poprzez to, co socjologie nazywają „upodobnianiem” ${ }^{30}$ się klasy robotniczej do średniej, kwestionują de facto istnienie tych rygorystycznych podziałów. Pisał o tym również Zbyszko Melosik, dowodząc, że współcześnie można delektować się dziełem operowym,

27 Por. D. Hejwosz-Gromkowska, Edukacja obywatelska we wspótczesnej Anglii.

28 J.P. Nederveen Pieterse, Globalization and culture, s. 61.

29 T. Edensor, National Identity, Popular Culture, s. 15.

30 Zob. A. Giddens, Elites in the British class structure, [w:] Elites and power in British society, red. P. Stanworth, A. Giddens, Cambridge 1974; tenże, The class structure of the advanced societies, London 1978. 
a po zakończeniu spektaklu udać się na posiłek do McDonalda i nie budzi to kontrowersji ${ }^{11}$. Z tej perspektywy wytwory kultury uległy fragmentaryzacji, rozproszeniu i multiplikacji, dlatego nie mogą one dłużej „udawać, że mają znaczenie narodowe ${ }^{\prime \prime 32}$. W tych warunkach trudniej poddać się narodowemu czy nacjonalistycznemu imperatywowi arbitralności kulturowej. Selekcja do narodowego panteonu autorytetów (a być może tylko "sław"33) nie zależy już od elity rządzącej, która utraciła swoją władzę w tym zakresie, oddając ją rozproszonym grupom interesu, przemysłowi kulturalnemu.

Warto zauważyć, że zarówno konstruowanie tożsamości narodowej, jak i jej ekspresja nie odbywają się jedynie w muzeum, na lekcjach historii, czy podczas ważnych wydarzeń państwowych, lecz w codziennych praktykach (można ponownie użyć kategorii R. Williamsa „zwyczajnej kultury”). I wydaje się, że to właśnie obszar życia codziennego jest miejscem, w którym dokonuje się kształtowanie tożsamości narodowej poprzez praktyki i wytwory popkulturowe.

Istota współczesnej tożsamości narodowej - nawiązując do Michaela Billiga $^{34}$ - bywa postrzegana jako banalna i ulegająca ekspresji w codziennych praktykach, a praktyki te odzwierciedlają charakter narodowy. Według Tima Edensora, tożsamość narodowa nie kształtuje się i nie wyraża jedynie poprzez konwencjonalną symbolikę, ale jest także doświadczana na poziomie lokalnym, a nawet domowym. Zrywa to zatem $\mathrm{z}$ tradycyjnym podejściem wobec procesu narodowotwórczego, tożsamości narodowej oraz kategorii narodu.

Według wspomnianej koncepcji T. Edensora i M. Billiga, brytyjskość byłaby wpisana zarówno w typowe miejsca symboliki narodowej, takie jak Big Ben, Białe Klify w Dover, czy Stonehenge, jak również w zwyczajne miejsca, na przykład w domki ogrodowe, kościoły, miejscowe atrakcje i tym podobne. W opinii T. Edensora,

tożsamość narodowa odgrywana jest zarówno w otoczeniu domowym, jak i miejscach ceremonii czy krajobrazach pamięci. Jest zakorzeniona w codziennych krajobrazach, pojawia się $\mathrm{w}$ domu poprzez prezentowane $\mathrm{w}$ telewizji spektakle, jest udomawiana dzięki wspólnemu lokalnemu sposobowi uczestnictwa w rytuałach narodowych, dyskutuje się o niej w rodzinach, miejscach pracy i pubach. To, co narodowe jest zatem na różne sposoby powiązane $\mathrm{z}$ tym, co lokalne. W istocie zestawienie sfery lokalnej i narodowej pozwala na zrozumienie każdej z nich; łączą się one w powszechnych, zdroworozsądkowych sytuacjach, w przestrzeniach codziennych, banalnych i nasyconych znaczeniem przedmiotach oraz w lokalnej różnorodności ${ }^{35}$.

\footnotetext{
${ }^{31}$ Zob. Z. Melosik, Tożsamość ciało i władza w kulturze instant.

32 T. Edensor, National Identity, s. 16.

33 Por. K. Trzęsicki, Celebryci i święci, [w:] Plaga celebrytów, red. W.K. Pessel, S. Zagórski,

${ }^{34}$ Zob. M. Billig, Banal Nationalism, London 1995.

35 T. Edensor, Tożsamość narodowa, kultura popularna, s. 237.
} Łomża 2013. 
Kultura popularna natomiast, szczególnie programy telewizyjne, filmy oraz muzyka pop, odzwierciedlają te codzienne, naturalne dla danego narodu praktyki. Można zatem stwierdzić, że wpływają one nie tylko na kształtowanie tożsamości narodowej, ale również na postawy obywatelskie.

Modernistyczne podejście do tak zwanej kultury wysokiej odrzucało eksponowanie zwyczajnych, codziennych praktyk w kształtowaniu tożsamości narodowej. Według takiego założenia, mogła ona rozwijać się jedynie w miejscach "uświęconych" poprzez słuchanie tych, którzy byli wybitnymi postaciami narodu, a bohaterowie ci po prostu nie prowadzili zwyczajnego życia codziennego. Tradycyjne podejście do kształtowania tożsamości narodowej ma charakter introwertyczny, zamknięty, zdefiniowany, skończony, nie podatny na interpretacje ${ }^{36}$. Przyjmuje się, że kształtowanie tożsamości narodowej najczęściej odbywa się w trakcie ważnych uroczystości (nawet tych banalnych, sportowych), doniosłych momentów, w kultywowaniu „wynalezionych tradycji”, w ciszy i zadumie. Jednak im bardziej globalizuje się współczesny świat, im granice są coraz bardziej zamazane, a tożsamości płynne, tym $\mathrm{w}$ większym stopniu renegocjacji i rekonstrukcji musi podlec tożsamość narodowa, która stopniowo przestaje być zamknięta, introwertyczna, gdyż zaczyna otwierać się na wiele różnych, często antagonistycznych i wykluczających się dyskursów. Wydaje się zatem, że tożsamość narodowa nie zanika, lecz podlega (re)konstrukcji, przestając być trwała i niekwestionowana. Ponowoczesność wraz z awansem kultury popularnej do kategorii analitycznej dały nowe otwarcie dla eksplorowania tożsamości narodowej i jej kształtowania. Kultura popularna nie tylko może kształtować tożsamość współczesnej młodzieży, ale także odzwierciedlać codzienne praktyki życia charakterystyczne dla danego narodu i obywatelskości.

\section{James Bond \\ jako egzemplifikacja współczesnych dylematów tożsamościowych Brytyjczyków}

Wyróżnionym przeze mnie popkulturowym symbolem Wielkiej Brytanii, a nade wszystko Anglii, jest fikcyjna postać, stworzona przez Iana Flaminga, znana jako James Bond. Popularność serii książek oraz filmów o przygodach angielskiego szpiega wydaje się dziś bezdyskusyjna. Fraza „nazywam się Bond, James Bond" znana jest nawet wśród tych osób, które nie czytały powieści ani nie oglądały filmów. Pierwsza książka o agencie 007, zatytułowana

${ }^{36}$ Zob. M. Skey, The national in everyday life: A critical engagement with Michael Billig's thesis of Banal Nationalism, The Sociological Review, 2009, 57(2). 
Casino Royale, została wydana w kwietniu 1953 roku, a nakład liczący 4750 woluminów w całości wyprzedano w miesiąc. Drugie wydanie ukazało się na rynku w kolejnym roku w nakładzie 8000 egzemplarzy. W 1954 roku wydano jednocześnie drugą książkę o przygodach Jamesa Bonda: Żyj i pozwól umrzeć (Live and Let Die), której nakład liczył ponad 9000 egzemplarzy. Pomimo zainteresowania tą powieścią szpiegowską, początkowa liczba sprzedanych woluminów nie była wcale imponująca. Ponadto, w Stanach Zjednoczonych trzy wydawnictwa odmówiły wydania Casino Royale, uzasadniając, że książka jest „zbyt brytyjska" (ostatecznie opublikowało ją brytyjskie wydawnictwo Macmillan, ale sprzedano mniej niż 4000 kopii). Przełom w dystrybucji powieści nastąpił w roku 1957, kiedy liczba sprzedanych trzech książek cyklu sięgnęła prawie 60 000, natomiast w roku w 1959 - blisko 200 400. Według Tony'ego Benneta, to właśnie ten rok stał się momentem narodzin nowego bohatera kultury popularnej, symbolu zimnej wojny. W odróżnieniu od rynku wydawniczego, sukces Jamesa Bonda na rynku filmowym był natychmiastowy, także na skalę międzynarodową ${ }^{37}$. Z każdym kolejnym rokiem popularność tekstów o Jamesie Bondzie, jak i sama jego postać, zyskiwały na popularności. Stał się on symbolem kultury popularnej oraz kultury upozorowania, „,̇̇yjąc” poza światem książek i filmów, wchodząc w świat reklam i programów telewizyjnych, przebijając się do prywatnego życia widza. Warto w tym miejscu przytoczyć słowa Tony'ego Benneta, opisującego fenomen Jamesa Bonda:

stał się obecny niemal w każdym domu, bywa punktem odniesienia w mowie potocznej, jest integralną częścią masowej świadomości, miał znaczenie nawet dla tych, którzy nigdy nie przeczytali żadnej książki o nim ani nie obejrzeli filmu. Ponadto jego popularność przekroczyła granice klasowe. Nie był rozpoznawany jedynie wśród metropolitalnej inteligencji, ani nie był politycznym bohaterem klasy średniej, nie - on stał się ikoną kultury popularnej dla przedstawicieli wszystkich klas społecznych, niezależnie od miejsca zamieszkania, roku urodzenia, płci i narodowości ${ }^{38}$.

Podobnie jak inni fikcyjni bohaterowie brytyjskiej literatury - Robin Hood, Sherlock Holmes, czy Harry Potter - tak i Bond stał się legendą oraz fenomenem popkultury, ale także symbolem Wielkiej Brytanii. Intertekstualność dzieła z udziałem Bonda obrazuje współczesne problemy polityczne i społeczne tego państwa. Narracja książek i filmów o Jamesie Bondzie odwołuje się także do kwestii globalnych ${ }^{39}$, współczesnych geopolitycznych problemów związanych głównie z bronią atomową oraz atakami terrorystycz-

37 T. Bennet, The Bond Phenomenon. Theorising a Popular Hero - A Retrospective, The International Journal of James Bond Studies, 2017, 1(1), s. 6.

${ }^{38}$ Tamże, s. 9.

${ }^{39}$ Por. C. Barmeyer, J. Scheffer, Over 50 Years on Culture's Service? Intercultural Competence and the Representation of Foreign Realities in James Bond Films, Studies in Media and Communication, 2016, 4(1). 
nymi, aczkolwiek opowiedzianych z lokalnego punktu widzenia, nawiązując często do brytyjskiej imperialnej nostalgii.

W powieściach o Bondzie Fleming nawiązywał do kwestii tożsamości narodowej, brytyjskości oraz angielskości. Główny bohater serii - w związku z wykonywaną profesją - nie czuje się w pełni Anglikiem, a w kolejnych częściach dowiadujemy się, że jego ojcem był Szkot, a po wyrzuceniu go z Eton edukację kontynuował w Szkocji (w adaptacji filmowej Skyfall pochodzenie Bonda jest wyjaśnione). Angielskość agenta 007 zostaje zakwestionowana również $\mathrm{w}$ kolejnych seriach książki, w których czytelnik dowiaduje się, że matka szpiega urodziła się w Szwajcarii ${ }^{40}$. Stopniowe "oczyszczanie" tej postaci $\mathrm{z}$ angielskości zapewniło $\mathrm{w}$ istocie filmom o losach najsłynniejszego szpiega sukces międzynarodowy. Uznany za symbol kultury popularnej, tekst o Jamesie Bondzie stał się zatem niewrażliwy na różnice kulturowe, jest więc rozumiany niezależnie od kultury, w której zostaje odczytywany ${ }^{41}$.

Jeśli chodzi o odtwórców roli Jamesa Bonda, warto zwrócić uwagę, że byli nimi kolejno: Szkot (Sean Connery), Australijczyk (Georege Lazenby), Anglik (Roger Moore), Walijczyk (Timothy Dalton), Irlandczyk (Pierce Brosnan) oraz Anglik (Daniel Craig). Z tej perspektywy wydawać się może, że postać Jamesa Bonda uwypukla wręcz dylematy tożsamościowe Brytyjczyków. Konstruowanie brytyjskości czy angielskości w powieści i filmach o Jamesie Bondzie przypadało na okres osłabienia politycznego Wielkiej Brytanii na arenie międzynarodowej, w wyniku uzyskiwania przez kolonie niepodległości oraz wysunięcie Stanów Zjednoczonych na pozycję międzynarodowego lidera. Spadek politycznego znaczenia Wielkiej Brytanii ujawnił się szczególnie w roku 1956, w czasie tak zwanego kryzysu sueskiego, kiedy Stany Zjednoczone wraz państwami Układu Warszawskiego wymusiły na Brytyjczykach, Francuzach i Izraelczykach wycofanie się z militarnej interwencji w Egipcie ${ }^{42}$.

Tożsamość Bonda skazana jest poniekąd na dynamiczność i podleganie ciągłej rekonstrukcji w zależności od sytuacji geopolitycznej, doboru aktorów, zmian społecznych i obyczajowych wyznaczających stosunek agenta do kobiet, wrogów, technologii i tym podobnych. Filmowa postać Jamesa Bonda - a zatem ta najbardziej znana na świecie - mimo zróżnicowanych kreacji aktorskich, posiada jednak trzy trwałe cechy, które konstruują ów tradycyjny

${ }^{40}$ Zob. J.P. Green, From Bringland With Love: National Identity and James Bond, [w:] Das kleine Bond-Buch. From cultural studies with love, red. E. Grunkemeier i in., Marburg 2007.

${ }^{41}$ Zob. J. Bennett, M. Bennett, Developing Intercultural Sensitivity. An integrative approach to global and domestic diversity, [w:] Handbook of Intercultural Training, red. D. Landis, J. Bennett, M. Bennett, London 2004; J. Hopkins, A Mapping of Cinematic Places. Icons, ideology, and the Power of (Mis) representation, [w:] Place, power, Situation and Spectacle. A Geography of Film, red. S.C. Aitken, L.E. Zonn, London 1994.

${ }^{42}$ C. Laucht, Britannia Rules the Atom: The James Bond Phenomenon and Postwar British Nuclear Culture, Journal of Popular Culture, 2013, 46(2), s. 360. 
etos angielskiego gentlemana, a tym samym wpisują się w dyskurs angielskości. Przede wszystkim, James Bond jest białym, heteroseksualnym mężczyzną, reprezentantem klasy uprzywilejowanej (edukacja w Eton i Cambridge). Jego męskość eksponowana jest powodzeniem u kobiet (z którego z radością korzysta), odwagę, sprawność fizyczną i intelektualną, a także muskularne i młode ciało. Ponadto, wykazuje niesłabnącą gotowość do podejmowania ryzyka, a być może jest nawet od niego uzależniony, jako że w każdym filmie obserwujemy scenę ukazującą jego zaangażowanie w hazard ${ }^{43}$. $Z$ tej perspektywy postać Bonda uosabia do pewnego stopnia cechy wpisujące się w tradycyjny dyskurs narodowości i obywatelskości w Anglii.

W pierwszą rolę Jamesa Bonda wcielił się Sean Connery ze swoim szkockim oraz „plebejskim” akcentem. W opinii Tony'ego Benneta, wybór Szkota na pierwsze filmowe wcielenie Bonda podyktowany był względami marketingowymi, gdyż jego postać miała spotkać się z zainteresowaniami amerykańskiej publiczności, przez co kreacja aktorska wydania Bonda miała przypominać innych amerykańskich bohaterów kultury popularnej. $\mathrm{W}$ ten oto sposób dokonano pierwszego poniekąd "oczyszczenia” postaci Bonda z typowych cech charakterystycznych dla angielskości. Miał więc on być „reprezentantem ludu”, bohaterem, który nie uosabia typowego arystokratycznego dystansu ${ }^{44}$. Obsadzenie $\mathrm{w}$ roli Bonda Seana Connery pozwoliło do pewnego stopnia wykreować postać "mniej” angielską, a bardziej globalną, nie reprezentującą określonej warstwy społecznej, co było zgodne z hasłami ruchów egalitarystycznych lat sześćdziesiątych. Niemniej jednak, mimo prób stworzenia postaci „bezklasowej”, przemawiającej z pozycji „zwykłego człowieka”, Bond posiada pewne dystynkcje wskazujące na jego pochodzenie społeczne. Odwołując się do kodów językowych Bernsteina ${ }^{45}$, postać Bonda posługuje się rozbudowaną formą, bliższą klasie średniej czy wyższej, a nie robotniczej. O jego pochodzeniu i przynależności klasowej nie mówi się explicite, jednak styl życia, otaczający go luksus (szczególnie samochód marki Aston Martin), a także uczęszczanie do Eton oraz Cambridge lokują go w wyższej warstwie społecznej. Trudno poniekąd oczekiwać, że najważniejszy brytyjski agent w społeczeństwie o sponsorowanej ruchliwości społecznej miałby być reprezentantem klasy robotniczej ${ }^{46}$. John Paul Green zauważa, że chociaż

${ }^{43}$ Zob. P. Raento, All in - and More! Gambling in the James Bond Films, UNLV Gaming Research \& Review Journal, 2017, 21(1).

44 T. Bennet, The Bond Phenomenon, s. 22. 2000.

${ }^{45}$ Zob. B. Bernstein, Pedagogy, symbolic control and identity: Theory, research, critique, London

${ }^{46}$ Zob. J. Black, The Politics of James Bond. From Fleming's Novels to the Big Screen, Lincoln - Nebraska 2005; D. Hejwosz, Edukacja uniwersytecka i ksztatcenie elit społecznych, Kraków 2010. 
Bond nie jest członkiem określonej klasy społecznej, nie stoi poza systemem klasowym, raczej go przekracza, lekceważąc bariery klasowe, w taki sam sposób jak pokonuje on geograficzne przeszkody w poszukiwaniu złoczyńców ${ }^{47}$.

Tony Bennet zauważa z kolei, że powieść i filmy o Jamesie Bondzie oddają „swingujący klimat” lat sześćdziesiątych poprzez dążenie do uwolnienia Wielkiej Brytanii z okowów społeczeństwa klasowego i prowadzenie nowoczesnego stylu życia ${ }^{48}$. W postaci Jamesa Bonda widoczny jest swoisty paradoks klasowy, z jednej strony manifestujący się przynależnością do wyższej klasy, plasując go obok innych romantycznych, arystokratycznych bohaterów znanych z literatury końca dziewiętnastego wieku (tzw. Clubland Heroes), z drugiej zaś - wpisujący się w merytokratyczny dyskurs lat sześćdziesiątych, który kształtował powojenne społeczeństwo brytyjskie ${ }^{49}$. Ambiwalencja tożsamościowa Bonda koresponduje z politycznym nastrojem tamtego okresu, wyrażającym się napięciami między tradycyjnymi wartościami a koniecznością wprowadzenia społecznych zmian i instytucjonalnych reform.

Przypomnę, że aktorzy wcielający się w rolę Jamesa Bonda byli Brytyjczykami, poza George'em Lazenby, który zagrał w jednym filmie: $W$ tajnej stużbie jej Królewskiej Mości (1969). Jak wskazuje J.P. Green, akcent tego aktora wykluczał go z dyskursu angielskości (brytyjskości), dlatego jego głos był dubbingowany przez angielskiego aktora George'a Bakera. Przywołany autor zwraca uwagę, że pojawienie się na ekranie w 1973 roku Anglika Rogera Moora, wystawiło angielskość poniekąd na granicę parodii, zanadto uwypuklając jej odrębność. W opinii J.P. Greena, gra aktorska Moora (siedem filmów w latach 1973-1985) była zbyt angielska, a Bond zamiast uosabiać cnoty wpisujące się w angielskość, stał się ich karykaturą ${ }^{50}$.

Kolejna - na ten moment ostatnia - odsłona dyskursywnej walki o angielskość Bonda to związanie tej postaci z aktorem Danielem Craigiem ${ }^{51}$. Będąc $\mathrm{w}$ historii produkcji drugim Anglikiem wcielającym się w rolę agenta 007, nie jest on już bliski pierwowzorowi zaproponowanemu przez I. Fleminga. Po pierwsze, jest blondynem (w mediach pojawiło się ironiczne określenie "James Blond”), po drugie - pochodzi z północy, co wyklucza jego "czystą" angielskość. Z tej perspektywy J.P. Green zauważa, że „prawdopodobnie mamy do czynienia z akceptacją nowej formy angielskości, która nie jest kojarzona jedynie z południem i nie posługuje się angielskim charakterystycznym dla stacji $\mathrm{BBC}^{\prime \prime 5}$. Jednak w opinii przywołanego autora, Bond w wydaniu Craiga

\footnotetext{
47 J.P. Green, From Bringland With Love, s. 85.

48 T. Bennet, The Bond Phenomenon, s. 8.

49 C. Laucht, Britannia Rules the Atom, s. 359; T. Bennet, The Bond Phenomenon, s. 8.

50 J.P. Green, From Bringland With Love, s. 85.

51 Por. C. Barmeyer, J. Scheffer, Over 50 Years on Culture's Service?, s. 66.

${ }^{52}$ J.P. Green, From Bringland With Love, s. 86.
} 
paradoksalnie jest najbliższy pierwowzorowi I. Fleminga - zdystansowany, chłodny, powściągliwy i panujący nad emocjami ${ }^{53}$.

Według badaczy przedmiotu, film Skyfall z 2012 roku jest niezwykle istotny z perspektywy Britishness. Jak twierdzi Barbara Korte, w tej części mamy do czynienia z repatriacją Bonda - przywrócona zostaje mu ojczyzna i tożsamość narodowa ${ }^{54}$. Po raz kolejny narracja filmowa wpisuje się $\mathrm{w}$ politykę rządu Wielkiej Brytanii, promując brytyjskość i korespondując z rodzącym się „nowym” brytyjskim patriotyzmem. Aczkolwiek według Jamesa Chapmana, narracja ostatnich filmów o Jamesie Bondzie nawiązuje do ogólnoświatowej debaty na temat nacjonalizmu, powracając ponownie do "patriotycznego kodu" charakterystycznego dla czasów zimnowojennych ${ }^{55}$. Ta część obfituje w symbole narodowe, szczególnie epatuje flagą Union Jack. Na uwagę zasługuje motyw figurki buldoga stojącej na biurku M, co stanowi jawne odwołanie, by posłużyć się Oxford Dictionary of Phrase and Fable, do tradycyjnego symbolu brytyjskiego charakteru uosabiającego odwagę i upór ${ }^{56}$. Ponadto, buldog jest również kojarzony z Winstonem Churchillem, a w filmie ukazana jest scena z bunkrów przeznaczonych dla premiera w okresie drugiej wojny światowej. Według Barbary Korte, przywoływanie symboli narodowych, w tym osoby Winstona Churchilla, kreuje na nowo tradycyjną i indywidualną heroiczność Bonda. Bohaterstwo to nie wyszło z mody, ale jest dostosowane do wymagań i potrzeb Brytyjczyków w XXI wieku ${ }^{57}$. Można zatem zauważyć, że dylematy tożsamościowe Bonda wpisują się w bieżącą dyskusję na temat obywatelstwa i dylematów tożsamościowych w Wielkiej Brytanii.

Tony Bennet analizując grę aktorów odtwarzających rolę Bonda, uważa, że postać ta ma charakter plastyczny, bowiem potrafi dopasować się do nowych wcieleń, przez co zawsze jest inna. W ten sposób staje się on „ruchomym symbolem", podatnym na różne style gry aktorskiej oraz na różne ideologie dominujące $\mathrm{w}$ danym momencie historycznym ${ }^{58}$. Bond staje się więc $\mathrm{w}$ istocie symbolem kultury upozorowanej, który funkcjonuje na granicy fikcji i rzeczywistości. Według tego podejścia, jego tożsamość - w dyskursie kultury popularnej - miesza się z tożsamością aktora, powodując hybrydyzację tożsamości ich obu. Ponadto, tożsamość Bonda już na zawsze wpisuje się w biografię

\footnotetext{
${ }^{53}$ Tamże.

${ }^{54}$ B. Korte, (Re-)Bonded to Britain: The Meta-Heroic Discourse of Skyfall, helden. heroes. héros. EJournal zu Kulturen des Heroischen, 2014, 1, s. 69.

${ }^{55}$ J. Chapman, Licence to Thrill: A Cultural History of the James Bond Films, London 2007, s. 158 ,

${ }^{56}$ Oxford Dictionary of Phrase and Fable, hasło bulldog, adres internetowy: http://www. oxfordreference.com/abstract/10.1093/acref/9780198609810.001.0001/acref-9780198609810e-1148?rskey=62XylZ\&result=1131 [dostęp: 24.06.2018].

57 B. Korte, (Re-)Bonded to Britain, s. 73.

${ }^{58}$ T. Bennet, The Bond Phenomenon, s. 12.
} 
i identyfikację aktora. Upozorowanie postaci Jamesa Bonda polega również na tym, że jego tożsamość fikcyjna jest mityczna, a urealnieniu ulega poprzez kreację każdego kolejnego aktora. W ten sposób Bond pozostaje wiecznie żywym symbolem zmieniającej się Wielkiej Brytanii. Doskonałą egzemplifikacją kultury upozorowania oraz Jamesa Bonda jako narodowego symbolu jest film inaugurujący otwarcie Olimpiady w 2012 roku w Londynie Happy and Glourious ${ }^{59}$. W tym sześciominutowym obrazie widzimy, między innymi, Jamesa Bonda granego przez Daniela Craiga, który reprezentuje instytucję korony, eskortując na stadion najważniejszego przedstawiciela Rodziny Królewskiej - Królową Elżbietę II, która w tym filmie pojawia się osobiście. W przywołanym obrazie fikcja (James Bond), semifikcja (Daniel Craig) miesza się z realną postacią Królowej, jej pałacem i psami. Film ten jest wyrazem hybrydyczności, w którym realna postać wchodzi w świat fikcji, instytucja staje się częścią dyskursu popkulturowego, z drugiej zaś strony świat fikcji staje się rzeczywisty w Pałacu Buckingham i otoczeniu Królowej. Na marginesie warto dodać, że pojawienie się Elżbiety II w tym obrazie związane było również z równoczesnymi obchodami sześćdziesięcioletniego jubileuszu sprawowania władzy oraz złotego jubileuszu filmów o Jamesie Bondzie. Obdarzony dawką specyficznego brytyjskiego humoru, film ten pokazuje monumentalność Wielkiej Brytanii, przywołując narodowe symbole: rodzinę królewską, Pałac Westminsterski, Winstona Churchilla, flagę Union Jack oraz heroicznego i szarmanckiego Jamesa Bonda. Wreszcie, wskazuje również na dystans Brytyjczyków i samej Królowej wobec siebie, gdyż w finale materiału filmowego Królowa "skacze” ze spadochronem. W tym kontekście T. Bennet stwierdza:

świat mitu, który zamieszkują bohaterowie kultury popularnej okazuje się być w istocie rzeczywisty. Sfera, w której się pojawiają ma charakter intertekstualny. Pełnią oni w niej funkcję „unoszącego się znaczenia” aktywnie produkujących przekaz, które krążą i wymieniają się między tekstami: mediując i łącząc się tekstualnie i intertekstualnie, aktywizują to co było, poprzez nadawanie znaczenia temu, co będzie ${ }^{60}$.

Koncepcja „unoszącego się znaczenia” czy też „pustego znaczenia” (floating lub empty signifier) pochodzi z prac Claude'a Levi-Straussa. Zakłada ona, że znak (symbol) nie posiada desygnatu $\mathrm{w}$ semiotyce oraz $\mathrm{w}$ analizie dyskursu, co znaczy, że słowo nie ma rzeczywistego czy też ustalonego znaczenia ${ }^{61}$. Przykład Bonda jest właśnie takim znaczeniem, który unosi się między

${ }^{59}$ Happy and Glourious, adres internetowy: https:/ / www.youtube.com/watch?v=1AS-dCdYZbo [dostęp: 8.03.2018].

60 T. Bennet, The Bond Phenomenon, s. 15.

${ }^{61}$ Zob. Oxford Reference, adres internetowy: http://www.oxfordreference.com/view/ 10.1093/oi/authority.20110803095824238 [dostęp: 20.04.2018]; J. Mehlman, The "Floating Signifier": From Lévi-Strauss to Lacan, Yale French Studies, 1972, 48. 
poszczególnymi postaciami, łącząc je w konstrukt, który występuje zarówno w powieściach, jak i filmach. Przemiany w tożsamości Bonda odpowiadają potrzebom publiczności i dostosowują ją do sytuacji geopolitycznej, pozwalają również na postawienie pytania, jakich bohaterów potrzebuje brytyjskie społeczeństwo?

Jak zasygnalizowałam wcześniej, intertekstualność filmów i powieści o Jamesie Bondzie pozwala na odczytywanie go w różnych kontekstach. Ich narracja nawiązuje do bieżących wydarzeń geopolitycznych, uosabiając Wielką Brytanię w postaci Jamesa Bonda jako bohatera ratującego świat przed zagrożeniami nuklearnymi z czasów zimnej wojny czy atakami terrorystycznymi w obecnych czasach (można by zatem oczekiwać, że najbliższa seria będzie poświęcona epidemii COVID-19, w której Bond w imieniu Wielkiej Brytanii będzie ratował świat przed skutkami rozprzestrzeniania się wirusa). $W$ ten oto sposób narracja tych tekstów kulturowych nawiązuje do potęgi gospodarczej, politycznej i militarnej z czasów imperialnych Wielkiej Brytanii. Pierwsze filmy osadzone były w czasach zimnowojennych uwarunkowań i odzyskiwania przez kolonie niepodległości, a James Bond chronił świat przed wrogimi siłami. W tym kontekście Jeremy Black zauważa, że zarówno filmy, jak i powieści o Jamesie Bondzie skupiały się na społecznych lękach, a obraz pokonywanych przez Bonda wrogów miał je łagodzić. W jego opinii, Bond jest nie tyle symbolem Wielkiej Brytanii, co świata zachodniego jako niezwyciężonego $^{62}$. Z kolei, Sameer Ahmed wskazuje, że filmy o Jamesie Bondzie nawiązują do idei Pax Britannica, gdyż agent 007 uosabia kulturalny imperializm oraz postimperialną męskość, a także eksponuje znaczenie i wpływy polityczne współczesnej Wielkiej Brytanii. Według badaczy przedmiotu - na których powołuje się S. Ahmed - nawet dziś duch i sentyment imperialny są przedstawiane w narracji o Jamesie Bondzie ${ }^{63}$.

Najczęściej Bond ratuje świat przed zorganizowanymi siłami zła, które straszą użyciem broni masowego rażenia. Odczytując teksty o Jamesie Bondzie, badacze zwracają uwagę na wiele metaforycznych obrazów łączących problematykę atomową ze światem agenta 007. Oto już w pierwszym filmie Doktor No dziewczyna Bonda, Honey Rider (grana przez Ursulę Anders), wynurza się $\mathrm{z}$ wody $\mathrm{w}$ kostiumie kąpielowym, znanym jako bikini. Słowo to oznacza również atol na Wyspach Marshalla, na którym testowano w latach czterdziestych amerykańską broń jądrową. W kolejnych filmach dziewczyny Bonda również pojawiają się w tym kostiumie, nawiązując jednocześnie do problematyki nuklearnej filmu. $\mathrm{Z}$ tej perspektywy niektórzy badacze zauważają, że strój bikini jest symbolem polityki nuklearnej światowych mocarstw,

${ }^{62}$ J. Black, The Geopolitics of James Bond, Intelligence and National Security, 2004, 19, s. 92.

${ }^{63}$ S. Ahmed, Fighting in the Shadows: Empire and Moral Regeneration in Skyfall, Media Education Journal, 2018, 63, s. 29. 
a postać Jamesa Bonda stała się wyrazem „kultury atomowej” ${ }^{64}$. Christopher Laucht utrzymuje, że przygody Jamesa Bonda

bardzo często są paralelne lub wręcz odzwierciedlają prowadzoną przez Brytyjczyków propagandę i politykę nuklearną, przedstawiając przy tym Wielką Brytanię jako atomowe supermocarstwo, jednocześnie przeceniając jej możliwości w tym zakresie, pomijając też znaczenie negatywnych skutków, w tym radioaktywnych odpadów ${ }^{65}$.

Ian Fleming wspomina w swych pracach o niebezpieczeństwie użycia broni nuklearnej, które mogą pozbawić życia miliony istnień ludzkich (zob. Moonraker), natomiast w filmach problematyka ta jest bagatelizowana lub pomijana, co korespondowało z prowadzoną ówcześnie brytyjską propagandą rządową na rzecz broni atomowej. Trywialne podejście do radioaktywnego promieniowania pokazane jest filmie Doktor No, kiedy związki promieniotwórcze zostają zwyczajnie zmyte z ciał głównych bohaterów. W następnej scenie Bond chwali doktora No za „efektywne radzenie sobie z radioaktywnym odpadem", co wzmacnia niekompetentny przekaz o skutkach radioaktywności. Według Christopha Lauchta, Doktor No odzwierciedla propagandę brytyjskiego rządu, która została ujęta w broszurze wydanej przez Ministerstwo Spraw Wewnętrznych w 1957 roku, a dotyczyła pożytków używania broni jądrowej, pomijając negatywne skutki jej użycia. Mimo tego, że pod koniec lat pięćdziesiątych w Stanach Zjednoczonych rozpoczęły się protesty ludności przeciwko broni nuklearnej, filmy o Jamesie Bondzie nadal trywializowały problem jej wykorzystania, a skutki jej użycia pokazywane były w sposób optymistyczny $^{66}$.

Polityka nuklearna wzmacniała zatem imperialny sentyment Brytyjczyków, ukazując zdolności mediacyjne Wielkiej Brytanii, gwarantującej pokój w okresie zimnej wojny. Narracja Jamesa Bonda wykreowała fikcyjną, niezależną pozycję Wielkiej Brytanii jako światowego nuklearnego supermocarstwa, stawiając ją na tej samej pozycji razem z USA i ZSRR ${ }^{67}$. Tak zwana kultura nuklearna $\mathrm{w}$ filmach o Jamesie Bondzie odgrywa znaczącą rolę w konstruowaniu brytyjskości. Po zakończeniu zimnej wojny pozycja Wielkiej Brytanii jako supermocarstwa została utrzymana w filmach o agencie 007. Narracja adaptacji filmowych z początku dwudziestego pierwszego wieku pomija kwestie użycia broni jądrowej, jedyny wyjątek to pojawienie się aktorki Halley Berry w stroju bikini w części zatytułowanej Śmierć nadejdzie jutro (2002), co nawiązywało do pierwszego odcinka serii Doktora No. Kolejne ekranizacje cyklu o agencie 007 odwołują się już do kwestii zagrożenia ter-

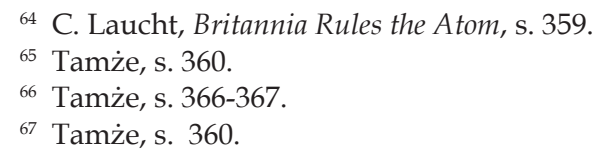


rorystycznego, wpisując się tym samym w rzeczywistość polityki światowej po 11 września. Na przykład, Casino Royal (2006) silnie osadzony jest w tej rzeczywistości, podobnie jak Skyfall (2012), który również podejmuje tematykę cyberterroryzmu. Jak zauważa Klaus Dodds, "film ten oddaje sytuację geopolityczną, pokazując relację między terrorem, szpiegostwem komputerowym a rolą Wielkiej Brytanii na świecie" ${ }^{68}$. Oto agent 007 musi odzyskać skradziony z MI6 twardy dysk, na którym znajdują się poufne dane dotyczące brytyjskich szpiegów, a przy okazji zobligowany jest do wykrycia źródła cyberataku na sieć komputerową agencji wywiadu. Dodds dokonując analizy tej części serii o agencie 007, zwraca uwagę, że tym razem brytyjskie służby specjalne radzą sobie ze stojącymi przed nimi wyzwaniami bez korzystania z pomocy amerykańskich sojuszników. Eksponowany jest również silny charakter Brytyjczyków oraz ich zdolność do zemsty. Bond jest uosobieniem szlachetnego szpiega kierującego się zasadami i broniącego Wielką Brytanię przed zewnętrznymi wrogami ${ }^{69}$.

Skyfall w opinii niektórych badaczy stanowi przełom w filmowej narracji o Jamesie Bondzie. Następuje bowiem w nim powrót do pierwowzoru postaci stworzonej przez I. Fleminga, który prezentuje agenta jako postać o skomplikowanej psychice, poszukującego swych korzeni i tożsamości, a jednocześnie zrywającego z typową heroicznością. Bond staje się zatem częścią dyskursu postmodernistycznego, jest bohaterem w czasach postheroicznych i ponownie musi negocjować swoją tożsamość oraz miejsce w świecie. Film ten nabiera również znaczenia z perspektywy wartości patriotycznych, gdyż przywraca się bohaterowi tożsamość narodową, co - powtórzę - stanowi repatriację Bonda. Według B. Korte, Skyfall jest odpowiedzią na lęki i niepokoje społeczeństw zachodnich XXI wieku, a zwłaszcza na kulturę strachu związaną z zagrożeniem terrorystycznym, obecną szczególnie w Wielkiej Brytanii i Stanach Zjednoczonych ${ }^{70}$. W tym kontekście należy zauważyć, że James Bond daje poczucie pewności w niestabilnych, niepewnych czasach. Popkulturowy bohater narodowy Brytyjczyków zawsze wygrywa z siłami zła, staje się metaforą Wielkiej Brytanii, która od zakończenia drugiej wojny światowej stara się utrzymać pozycję światowego mocarstwa.

Filmy o Jamesie Bondzie odnoszą międzynarodowy sukces, stając się nośnikami wartości i kultury brytyjskiej, która ma charakter hybrydyczny. Na przykład, auto Aston Martin z jednej strony symbolizuje tradycję i niezmienność oraz brytyjski luksus i elegancję, z drugiej zaś stanowi globalną reklamę

${ }^{68}$ K. Dodds, Popular Geopolitics and War on Terror, [w:] Popular Culture and World Politics: Theories, Methods, Pedagogies, red. F. Caso, C. Hamilton, E-international relations, Bristol 2015, s. 59.

${ }^{69}$ Tamże.

${ }^{70}$ B. Korte, (Re-)Bonded to Britain, s. 69. 
tej marki samochodu. Ponadto, ukazuje kompetencje międzykulturowe Bon$\mathrm{da}^{71}$ (a tym samym zapewne Wielkiej Brytanii), jego siłę w walce z globalnym terroryzmem, a jednocześnie skupiając narrację wokół jego pochodzenia i lojalności wobec korony. Walka z terrorem daje możliwość ponownego ukazania siły Jamesa Bonda, a tym samym Wielkiej Brytanii. Po pierwsze, w narracji filmowej jej agenci odgrywają kluczową rolę, po drugie, James Bond - obok Robin Hooda i Harry'ego Pottera - jest jednym z najbardziej znanych symboli popkulturowych Wielkiej Brytanii, z powodzeniem konkurując z amerykańskimi postaciami kultury masowej ${ }^{72}$.

Tożsamość Jamesa Bonda kształtowana jest na pograniczu angielskości i brytyjskości, co wpisuje się we współczesną debatę na temat tożsamości Brytyjczyków. Chociaż Bond z pochodzenia jest Szkotem, to posiada typowe cechy wpisujące się $\mathrm{w}$ angielską tożsamość przedstawiciela klasy średniej. Bez wątpienia, hybrydyczność tożsamości narodowej Bonda odzwierciedla niepokoje tożsamościowe we współczesnej debacie Brytyjczyków. Szkotem jest z pochodzenia, wykonywany zawód nakazuje mu chronienie Wielkiej Brytanii, natomiast edukacja i zachowanie wskazują na angielskość. W tym kontekście wydaje się, że postać Jamesa Bonda eksponuje cechy tożsamości angielskiej, utrzymując i reprodukując mit męskiego superbohatera. Nawiązując do bieżących wydarzeń politycznych, Bond pozostaje nadal wyrazem imperialnych nostalgii Wielkiej Brytanii. Agenta 007 nie można zabić, tak samo jak nie można pokonać Wielkiej Brytanii. Jako bohater popkultury, a jednocześnie narodowy bohater, jest uosobieniem tych cech, jakie przypisuje się Zjednoczonemu Królestwu: indywidualność, odrębność i niezwyciężoność. $Z$ tej perspektywy, w konkluzji należałoby stwierdzić, że słowa Kingsleya Amisa zawarte w mottcie niniejszego artykułu pozostają nadal aktualne.

\section{BIBLIOGRAFIA}

Ahmed S., Fighting in the Shadows: Empire and Moral Regeneration in Skyfall, Media Education Journal, 2018, 63.

Amis K., The James Bond Dossier, The American Library, New York 1965.

Andrews R., Mycock A., Dilemmas of Devolution: The 'Politics of Britishness' and Citizenship Education, British Politics, 2008, 3.

Barmeyer C., Scheffer J., Over 50 Years on Culture's Service? Intercultural Competence and the Representation of Foreign Realities in James Bond Films, Studies in Media and Communication, 2016, 4(1).

Beck J., A brief history of citizenship education in England and Wales, [w:] Debates in citizenship education, red. J. Arthur, H. Cremin, Routledge, London and New York 2012.

${ }^{71}$ Zob. C. Barmeyer, J. Scheffer, Over 50 Years on Culture's Service?

72 B. Korte, (Re-)Bonded to Britain, s. 69. 
Bennet T., The Bond Phenomenon. Theorising a Popular Hero - A Retrospective, The International Journal of James Bond Studies, 2017, 1(1).

Bennett J., Bennett M., Developing Intercultural Sensitivity. An integrative approach to global and domestic diversity, [w:] Handbook of Intercultural Training, red. D. Landis, J. Bennett, M. Bennett, Sage, London 2004.

Bernstein B., Pedagogy, symbolic control and identity: Theory, research, critique, Rowman \& Littlefield, London 2000.

Billig M., Banal Nationalism, Sage, London 1995.

Black J., The Geopolitics of James Bond, Intelligence and National Security, 2004, 19.

Black J., The Politics of James Bond. From Fleming's Novels to the Big Screen, University of Nebraska Press, Lincoln - Nebraska 2005.

Chapman J., Licence to Thrill: A Cultural History of the James Bond Films, Tauris, London 2007.

Dodds K., Popular Geopolitics and War on Terror, [w:] Popular Culture and World Politics: Theories, Methods, Pedagogies, red. F. Caso, C. Hamilton, E-international relations, Bristol 2015.

Edensor T., National Identity, Popular Culture and Everyday Life, Berg, Oxford 2002.

Edensor T., Tożsamość narodowa, kultura popularna i życie codzienne, przekł. A. Sadza, Wydawnictwo Uniwersytetu Jagiellońskiego, Kraków 2004.

Featherstone M., Global culture: An introduction, Theory, Culture \& Society, 1990, 7(2-3).

Giddens A., Elites in the British class structure, [w:] Elites and power in British society, red. P. Stanworth, A. Giddens, Cambridge University Press, Cambridge 1974.

Giddens A., The class structure of the advanced societies, Hutchinson of London, London 1978.

Green J.P., From Bringland With Love: National Identity and James Bond, [w:] Das kleine Bond -Buch. From cultural studies with love, red. E. Grunkemeier i in., Schuren Press, Marburg 2007.

Happy and Glourious, adres internetowy: https://www.youtube.com/watch?v=1AS-dCdYZbo [dostęp: 8.03.2018].

Hejwosz D., Edukacja uniwersytecka i ksztatcenie elit społecznych, Oficyna Wydawnicza Impuls, Kraków 2010.

Hejwosz-Gromkowska D., Edukacja obywatelska we wspótczesnej Anglii. Studium socjopedagogiczne, Wydawnictwo Naukowe UAM, Poznań 2019.

Hodkinson P., Media, culture and society. An introduction, Sage, London 2011.

Hoogvelt A., Globalisation and the postcolonial world, Palgrave, London 1997.

Hopkins J., A Mapping of Cinematic Places. Icons, ideology, and the Power of (Mis) representation, [w:] Place, power, Situation and Spectacle. A Geography of Film, red. S.C. Aitken, L.E. Zonn, Rowman \& Littlefield Publishers, London 1994.

Korte B., (Re-)Bonded to Britain: The Meta-Heroic Discourse of Skyfall, helden. heroes. héros. EJournal zu Kulturen des Heroischen, 1, 2014.

Kumar K., The Making of English National Identity, Cambridge University Press, Cambridge 2003.

Kumar K., English and French national identity: comparisons and contrasts, Nations and Nationalism, 2006, 12(3).

Laucht C., Britannia Rules the Atom: The James Bond Phenomenon and Postwar British Nuclear Culture, Journal of Popular Culture, 2013, 46(2).

Layton-Henry Z., Citizenship and nationality in Britain, [w:] Challenging racism in Britain and Germany, red. Z. Layton-Henry, C. Wilpert, Palgrave Macmilian, London 2003.

Malik A., Citizenship education, race and community cohesion, [w:] Debates in citizenship education, red. J. Arthur, H. Cremin, Routledge, London - New York 2012.

Mehlman J., The "Floating Signifier": From Lévi-Strauss to Lacan, Yale French Studies, 1972, 48. 
Melosik Z., Tożsamość, ciało i władza. Teksty kulturowe jako (Kon)teksty pedagogiczne, Wydawnictwo Edytor, Torun - Poznań 1996.

Melosik Z., Kryzys męskości w kulturze wspótczesnej, wyd. II poprawione, Oficyna Wydawnicza Impuls, Kraków 2006.

Melosik Z., Teoria i praktyka edukacji wielokulturowej, Oficyna Wydawnicza Impuls, Kraków 2007.

Melosik Z., Tożsamość ciało i władza w kulturze instant, Oficyna Wydawnicza Impuls, Kraków 2010.

Melosik Z., Kultura popularna i tożsamość młodzieży. W niewoli władzy $i$ wolności, Oficyna Wydawnicza Impuls, Kraków 2013.

Nederveen Pieterse J.P., Globalization and Culture: global mélange, Rowman and Littlefield, Lanham 2009.

Osler A., Citizenship education, democracy and racial justice 10 years on, Race Equality Teaching, 2009, 27(3).

Oxford Dictionary of Phrase and Fable, hasło bullog, adres internetowy: http:/ / www.oxford reference.com/abstract/10.1093/acref/9780198609810.001.0001/acref-97801986098 10-e-1148?rskey=62XylZ\&result=1131 [dostęp: 24.06.2018].

Oxford Reference, adres internetowy: http://www.oxfordreference.com/view/10.1093/ oi/authority.20110803095824238 [dostęp: 20.04.2018].

Park A., Bryson C., Curtice J., British Social Attitudes 31, NatCen 2014, adres internetowy: http://www.bsa.natcen.ac.uk/media/38893/bsa31_full_report.pdf [dostęp: 20.04 . 2018].

Raento P., All in - and More! Gambling in the James Bond Films, UNLV Gaming Research \& Review Journal, 2017, 21(1).

Sales R., What is 'Britishness', and is it important?, [w:] Citizenship acquisition and national belonging, red. G. Calder, D. Cole, J. Seglow, Palgrave Macmillan, London 2010.

Skey M., The national in everyday life: A critical engagement with Michael Billig's thesis of Banal Nationalism, The Sociological Review, 2009, 57(2).

Szkudlarek T., Television as adult pedagogy: Learning Consumersim, Dreaming, Democracy, [w:] Adult Education and Democratic Citizenship, red. A. Bron, J. Field, E. Kurantowicz, Oficyna Wydawnicza Impuls, Kraków 1998.

Trzęsicki K., Celebryci i święci, [w:] Plaga celebrytów, red. W.K. Pessel, S. Zagórski, Oficyna Wydawnicza Stopka, Łomża 2013.

Ward P., The end of Britishness? A historical perspective, British Politics Review, 2009, 4(3). 